\title{
Obesity, Type 1 Diabetes, and Psoriasis: An Autoimmune Triple Flip
}

\author{
Mariagrazia Granata Evangelia Skarmoutsou Chiara Trovato Giulio A. Rossi \\ Maria Clorinda Mazzarino Fabio D'Amico \\ Department of Biomedical and Biotechnological Sciences, University of Catania, Catania, Italy
}

\section{Key Words}

Adipokines - Autoimmune diseases - Cytokines - Diabetes ·

MicroRNA · Obesity · Psoriasis

\begin{abstract}
Obesity, type 1 diabetes, and psoriasis are wide-ranging health problems. Genetics, epigenetics, and environmental factors together with immune disturbances are involved in these diseases. The white adipose tissue is an active endocrine organ, secreting a wide variety of soluble mediators called adipokines that have a central role in the relationship between adipose tissue and immune system. Inflammatory cytokines, including the IL-23/IL-17 and IL-18 axes, and microRNAs are involved in many processes, including immunity and inflammation, thus having a major role in the onset of these three diseases. In this review, we present an overview of the roles of adipokines, cytokines, and microRNAs in the pathogenesis and the progression of these three diseases.
\end{abstract}

(c) 2016 S. Karger AG, Basel

\section{Introduction}

The pathophysiology of autoimmune diseases involves genetics, epigenetics, and environmental factors, together with immune disturbances. Many literature data con-

\section{KARGER}

(c) 2016 S. Karger AG, Basel

E-Mail karger@karger.com

www.karger.com/pat cerning the association between diet and the risk of developing autoimmune diseases are available [1]. The 'Western lifestyle' and a diet characterized by the use of high-fat, high-sugar, high-salt foods are involved in the development of autoimmunity, and the lack of physical activity in combination with excess calorie intake causes a high prevalence of obesity in developed societies [2, 3]. Obesity, in turn, predisposes to different diseases, and it is becoming increasingly clear that the dietary habits in Western societies and a high body mass index (BMI) also constitute risk factors for autoimmune diseases [4].

Once considered as an inactive energy storage tissue, the white adipose tissue has been discovered as an active endocrine organ, secreting a wide variety of soluble mediators termed 'adipokines' or 'adipocytokines' [5]. This group of cytokines has a key role in different processes, including immunity and inflammation. In particular, most of them have proinflammatory action and are involved in the 'low-grade inflammatory state' in obese subjects [6]. The most relevant adipokines are leptin, adiponectin, resistin, and visfatin.

Leptin has a key role in energy homeostasis: it promotes satiety and stimulates energy expenditure [7]. Furthermore, its serum levels are strongly correlated with the body fat mass and adipocyte size. Obese individuals show high levels of leptin expression in adipose tissue and in the systemic circulation. However, these high leptin levels 
fail to reduce excess adiposity, a pathophysiologic status known as leptin resistance [8].

Leptin, up-regulated by inflammatory mediators such as tumor necrosis factor (TNF), IL-1 $\beta$, and insulin, promotes the release of proinflammatory cytokines such as TNF, IL-12, and IL-6 $[9,10]$. In obese individuals, increased leptin production leads to a reduction in adipose tissue-infiltrating regulatory $\mathrm{T}$ cells $\left(\mathrm{T}_{\text {reg }}\right)$, thus amplifying local inflammation $[7,11]$. $\mathrm{T}_{\text {reg }}$ are a subset of $\mathrm{CD} 4+$ CD25+ T cells, known as crucial mediators of immune tolerance [12].

Adiponectin is involved in the metabolic regulation and, similarly to leptin, is an insulin-sensitizing adipokine. Adiponectin reduces the secretion and the activity of TNF and IL-6, and induces the production of anti-inflammatory mediators, such as IRAK-1 (IL-10 and IL-1 receptor antagonist), in macrophages, monocytes, and dendritic cells. Adiponectin also enhances the number of $\mathrm{T}_{\text {reg }}$ cells $[13,14]$. This cytokine is a key link between obesity and autoimmunity: despite being secreted by the adipose tissue, its levels are decreased in the serum of overweight patients and increased with calorie restriction [15-17]. TNF and IL-6 are efficient inhibitors of adiponectin secretion, suggesting the presence of a negative feedback between adiponectin and proinflammatory cytokines [6].

Proinflammatory cytokines, such as TNF, IL- $1 \beta$, and IL-6, increase the expression of resistin in human peripheral blood mononuclear cells [6]. In both rodents and humans, resistin serum levels increase with obesity $[18,19]$. Different studies in animal models have shown that resistin promotes insulin resistance. However, in humans, resistin may be involved in inflammatory processes instead of in the glucose homeostasis modulation.

Visfatin increases the leukocyte production of inflammatory cytokines IL- 6 , TNF, and IL- $1 \beta$. Furthermore, it is involved in the activation of T cells, stimulating the expression of costimulatory molecules, such as CD54, CD80, and CD40 on monocyte surface. Visfatin has an important role in the development of both $\mathrm{B}$ and $\mathrm{T}$ lymphocytes and it acts as chemotactic factor for lymphocytes and monocytes. Together with resistin, visfatin is up-regulated by inflammatory mediators [20].

Type 1 diabetes (T1D) is a chronic disease due to the autoimmune destruction of insulin-producing $\beta$ cells in the pancreas, leading to an abnormal regulation of glucose homeostasis in T1D patients [21,22]. It is supposed that $90 \%$ of insulin-secreting $\beta$ cells are destroyed due to autoimmune mechanisms driven by CD8+ and CD4+ T lymphocytes and proinflammatory cytokines. Abroga- tion of CD4+ CD25+ FoxP3+ $\mathrm{T}_{\text {reg }}$ cells can break tolerance towards islet cell antigens in the pancreas, provoking T1D [23]. More recently, $\mathrm{T}_{\mathrm{H}} 17$-dependent immunity has been demonstrated to be involved in the onset of autoimmune diabetes in animal models. In nonobese diabetic (NOD) mice, a model of spontaneous autoimmune diabetes, inhibition of $\mathrm{T}_{\mathrm{H}} 17$ cells has been shown to mitigate autoimmune diabetes $[24,25]$. In humans, the role of $\mathrm{T}_{\mathrm{H}} 17$-dependent immunity in T1D is not fully clarified [26], even if many data show that the up-regulation of the IL-17 response has been associated with other immunemediated diseases, such as multiple sclerosis, psoriasis, rheumatoid arthritis, and inflammatory bowel diseases [27]. Furthermore, the participation of IL- $1 \beta$, IFN- $\gamma$, and TNF in T1D is well known [28]. TNF and IFN- $\gamma$, released by infiltrating macrophages, are involved in pancreatic $\beta$ cell apoptosis through activation of calcium channels, which, in turn, induce caspase activation [29].

Psoriasis is a chronic inflammatory autoimmune-mediated skin disorder [30]. It can occur at any age, although it most commonly appears for the first time in late adolescence or early adulthood and then usually persists for life [31]. Abnormal keratinocyte function, as well as the $\mathrm{T}_{\mathrm{H}} 1$-mediated condition due to the large number of IFN- $\gamma$-secreting $\mathrm{T}$ cells in the epidermis, are strictly involved in the onset of psoriasis [32]. In psoriatic lesions, the most represented $\mathrm{T}$-cell populations are $\mathrm{T}_{\mathrm{H}} 1, \mathrm{~T}_{\mathrm{H}} 22$, and $\mathrm{T}_{\mathrm{H}} 17$ [32]. Several authors have shown that different cytokines, including transforming growth factor $\beta$ (TGF $\beta$ ), IL-6, IL-1, and IL-21, are involved in the differentiation of $\mathrm{T}_{\mathrm{H}} 17$ cells. Furthermore, IL-23 has been found to have a key role in the maintenance and proliferation of differentiated $\mathrm{T}_{\mathrm{H}} 17$ cells [31]. In addition to the recruitment of inflammatory $\mathrm{T}$ cell subsets, elevated levels of $\mathrm{T}_{\text {reg }}$ cells have been observed in patients with psoriasis, and increasing levels of these cells correlate with disease severity $[33,34]$. Authors have found that $\mathrm{T}_{\text {reg, }}$, in the presence of proinflammatory cytokines such as IL- $1 \beta$ and IL-6, can produce the proinflammatory cytokine IL17. Therefore, $T_{\text {reg }}$ may have a role in perpetuating, rather than in suppressing, inflammatory processes [35]. Recently, it has been found that IL-6, IL-23, and IL-21 may induce signal transducer and activator of transcription 3 (STAT3) phosphorylation of $\mathrm{T}_{\text {reg }}$ cells in psoriasis. STAT3 pathway results in impaired function of $\mathrm{T}_{\text {reg }}$ cells, which produce IL-17, IFN- $\gamma$, and TNF [36].

A growing number of studies support an involvement of the IL-18 axis in the pathogenesis of psoriasis [37]. For reasons not fully understood, patients with an organ-specific autoimmune disease have increased risks of develop-
72

Pathobiology 2017;84:71-79

DOI: $10.1159 / 000447777$
Granata/Skarmoutsou/Trovato/Rossi/ Mazzarino/D’Amico 
ing autoimmune responses against other organs or tissues. Patients with T1D have been shown to have a higher susceptibility to develop other autoimmune diseases, such as psoriasis [23]. Recent studies have shown that patients with psoriasis are more inclined to be obese than healthy controls and that obesity is more common in patients with severe rather than mild psoriasis [38]. Finally, several adipokines have a central role in the low-grade inflammatory state in obese subjects, inducing autoimmune and inflammatory diseases such as T1D and psoriasis $[39,40]$. The aim of this review is to present an outlook of the roles of adipokines, cytokines, and microRNAs (miRNAs) in the onset and maintenance phases of these three diseases.

\section{The IL-23/IL-17 Axis}

The IL-23/IL-17 axis is strictly involved in the pathogenesis of obesity and psoriasis. Moreover, there is a growing evidence that this axis may also be involved in T1D. $\mathrm{T}_{\mathrm{H}} 17$ cells mediate the inflammation associated with tissue-specific autoimmune diseases. Aberrant $\mathrm{T}_{\mathrm{H}} 17$ responses have been implicated in a growing list of autoimmune disorders [41]. $\mathrm{T}_{\mathrm{H}} 17$ cells can be activated through different pathways. TGF $\beta$, in synergy with IL-6, has a key role in generating de novo $\mathrm{T}_{\mathrm{H}} 17$ cells [42]. TGF $\beta$ is also implicated in the differentiation of Foxp $3+\mathrm{T}_{\text {reg }}$ cells [43]. Interestingly, IL-6 can break the homeostasis in the immune tolerance inhibiting the TGF $\beta$-driven $\mathrm{T}_{\text {reg }}$ differentiation and, as already mentioned, promoting the $\mathrm{T}_{\mathrm{H}} 17$ differentiation [44]. Moreover, it has been found that TGF $\beta$ upregulates IL-23 receptor $\alpha$ chain expression (IL23R), thus conferring reactivity to IL-23 that can play a key role in the survival and commitment of $\mathrm{T}_{\mathrm{H}} 17$ cells [45]. Other authors have also shown an IL-6-driven IL-23R up-regulation on naïve $\mathrm{CD} 4+\mathrm{T}$ cells through STAT3, as well as a synergic function of IL-6 and IL-23 in promoting $\mathrm{T}_{\mathrm{H}} 17$ differentiation [46]. IL-6 increases TGF $\beta$ mRNA levels in naïve CD4+ T cells, thus underlining that IL-6- and IL-23-driven $\mathrm{T}_{\mathrm{H}} 17$ activation is dependent on TGF $\beta$ [42]. IFN- $\gamma$ and IL-4 can inhibit the action of TGF $\beta$ on T cells, representing an important pathway by which these cytokines suppress $\mathrm{T}_{\mathrm{H}} 17$ differentiation [45]. Differentiated $\mathrm{T}_{\mathrm{H}} 17$ cells produce cytokines such as IL-17A, IL-17F, IL-21, and IL-22 [47].

Recent studies have observed that serum levels of leptin, IL-17, and IL-23 are significantly higher in obese subjects compared with lean controls. In particular, a study based on obese women has shown a correlation be-

Autoimmune Interplay among Obesity, Diabetes, and Psoriasis tween serum levels of IL-17, IL-23, and increased weight, thus underlining a role for IL-17 and IL-23 as potential markers of the inflammatory syndrome that characterizes obesity. Adipose tissue, together with its infiltrating immune cells, is an important source of proinflammatory mediators and represents a possible cellular source of IL17 and IL-23 in obese patients $[48,49]$.

Several studies have indicated an increase in IL-17 production in humans with T1D, especially in the very early stages of disease [50]. Monocytes from T1D patients have shown increased levels of IL-6 mRNA, giving a potential explanation for increased IL-17 production [51]. $\beta$ cell survival and function may be impaired by IL- $1 \beta$, which is also able to promote IL-17 production [52]. It has been shown that $\mathrm{T}$ cells isolated from pancreatic lymph nodes of T1D patients undergoing pancreas transplant had a higher frequency of $\mathrm{T}_{\mathrm{H}} 17$ cells than healthy controls [53]. Interestingly, in autoimmune diseases, a separate population of $T_{H}$ cells, the $T_{H} 1 / T_{H} 17$ cells that co-produce both IL-17 and IFN- $\gamma$, has been found [54]. Several studies have found an increased polarization of IL-17+ cells to produce IFN- $\gamma$ in children with T1D compared with healthy controls $[55,56]$. Thus, the presence of $\mathrm{T}_{\mathrm{H}} 1 / \mathrm{T}_{\mathrm{H}} 17$ cells could potentially be a hallmark of T1D, even if further investigation is required.

Psoriasis is a $\mathrm{T}_{\mathrm{H}} 1$ - and $\mathrm{T}_{\mathrm{H}} 17$-driven disease [57]. Inflammatory stress signals from keratinocytes activate dendritic cells (DCs) that can switch naive CD4+ T cells into $\mathrm{T}_{\mathrm{H}} 17$ ones [58]. The IL-23/IL-17 axis plays a crucial role in the inflammatory and proliferative pathway of both psoriatic skin and joint tissues [33]. Moreover, IL-17 serum levels in psoriatic patients have been shown to be increased compared to healthy controls [59] and $\mathrm{T}_{\mathrm{H}} 17$ cell levels were higher in psoriatic plaques than in controls [60].

\section{The IL-18 Axis}

IL-18 is a cytokine that plays an important role in the $\mathrm{T}_{\mathrm{H}} 1$ response. Pleiotropic effects of IL-18, especially the induction of IFN $\gamma$, are essential for immunity against invading pathogens. However, improper regulation of IL18 can potentially lead to inflammation and destruction of self. This cytokine is synthetized as an inactive form that requires to be processed by caspase- 1 into its active form [37].

IL-18 is one of the cytokines that have been found to be produced and released from human adipose tissue [61, 62 ]. Many studies have shown a strong evidence that IL- 
18 also has an important role in regulating energy homeostasis. Adipocytes from obese subjects secrete more IL-18 than those from lean controls [63]. In humans, circulating IL-18 levels positively correlate with BMI, adiposity, type 2 diabetes, or insulin resistance, hypertriglyceridemia, and metabolic syndrome $[64,65]$. Furthermore, it has been observed a strong relationship between the chronic low-grade inflammatory state and its associated metabolic syndrome disorders due to increased adipokine release from accumulating white adipose tissue [64, 66].

IL-18 has also been reported to be involved in both the pathogenesis and progression of T1D. Genes for both mouse and human IL-18 are located in genetic regions associated with susceptibility to T1D $[67,68]$. Different studies have reported increased serum IL-18 levels in patients with T1D, and this increase was correlated with glycated hemoglobin $\left(\mathrm{HbA}_{1 \mathrm{C}}\right)$ levels, suggesting a link between hyperglycemia and IL-18 $[69,70]$. In NOD mice, pancreatic $\beta$ cells can produce IL-18, and enhanced expression of this cytokine results in destructive insulitis in these mice [71]. IL-18 protein expression was also observed within the pancreatic islets of patients with fulminant T1D [72]. Furthermore, a significant association between elevated IL-18 serum levels and increased numbers of autoantibodies detected was shown in new-onset T1D patients [73].

Concerning psoriasis, many immunohistochemical studies have shown that keratinocytes from healthy and psoriatic skin samples constitutively express IL-18 [74, 75]. However, IL-18 levels were higher in active and progressive psoriatic lesions than in those from patients with stable disease [76]. In psoriatic patients, serum IL-18 levels were increased [77]. Epidermal DCs express IL-18 receptor and, after IL-18-driven stimulation, show actin polymerization, a sign of increased migratory tendency [78].

\section{Role of the Epigenetic Control: miRNAs}

miRNAs are small non-protein-coding RNAs that negatively regulate gene expression at the post-transcriptional level targeting the $3^{\prime}$-untranslated region of a specific mRNA transcript [79]. miRNAs are main regulators of cellular pathways and networks, performing key roles in different biological processes and diseases [80-82]. Molecular phylogenetic studies have shown that a large number of miRNA sequences are highly conserved among species, thus underlining their key role in molecular pathways crucial for cell survival [83].
Several miRNAs, such as miR-21 and miR-146a, are prevalently expressed in immune cells, including $\mathrm{T}_{\text {reg }}$ cells, which are known to be critical players in immune tolerance $[84,85]$. Dysregulation of miRNA expression or mutation in miRNA genes or in their binding sites are associated with a wide variety of human diseases, including autoimmune and inflammatory disorders [86].

Many studies on murine models have found that miR21 and miR-146a are potentially involved in adipocyte differentiation through targeting C/EBP $\beta$ (CCAAT-enhancer-binding protein- $\beta$ ) [87] and apolipoprotein E, respectively [88]. miR-21 has been shown to play a central role in the differentiation and function of both white and brown adipose tissue, and it is positively correlated with BMI in subcutaneous adipose tissue [89]. In preadipocyte proliferation, miR-146b is able to promote the transition to terminal differentiation, thus enhancing adipogenesis [90].

Recent studies have found that the expression of miR$146 a$ and miR-146b-5p was significantly lower in newly diagnosed T1D patients compared with controls. Six genes were identified as target genes of miR-146a and miR-146b-5p: BCL11A, NUMB, STX3, KLF7, GRID1, and $P B X 2$. These genes are associated with the risk of diabetes [91]. In pancreatic $\beta$ cells, c-Rel and p65 activate miR-21 gene promoter, thus increasing its RNA levels. miR-21 down-regulates PDCD4 (programmed cell death protein 4) levels, thus protecting cells from Bax family-mediated apoptosis. Thus, the miR-21-PDCD4 axis may play a crucial role in T1D, representing a potential therapeutic target for treating the disease [92].

miR-21 is significantly up-regulated in psoriatic skin lesions compared to healthy skin [93]. Moreover, a positive correlation between miR-21 levels in $\mathrm{T}$ cells from psoriatic patients and disease activity has been found [94]. Concerning this association, recent studies have shown that miR-21 expression in psoriatic skin inflammation is suppressed by UV therapy [95]. Increased level of miR-21 in psoriasis could be explained by its involvement in $\mathrm{T}_{\mathrm{H}} 17$ polarization as shown in a model of experimental autoimmune encephalomyelitis [96]. Moreover, miR-21 is able to activate TACE (TNF $\alpha$-converting enzyme) through the down-regulation of epidermal TIMP3 (tissue inhibitor of matrix metalloproteinase 3), the natural inhibitor of active TACE [97]. miR-146a, expressed in monocytes and macrophages by various Toll-like receptor ligands and pro-inflammatory cytokines, has been found overexpressed in psoriatic skin compared to controls $[98,99]$. miR-146a, through its targeting action on IRAK-1 and TRAF-6 (TNF receptor-associated factor-6) 
Fig. 1. Schematic representation of interactions between cytokines/adipokines in adipose tissue and obesity, psoriasis, and T1D. In obese subjects, resistin, leptin, and visfatin levels are increased while adiponectin levels are decreased (a). Visfatin and leptin increase IL-6 levels (b). This cytokine decreases adiponectin levels (c) and enhances resistin levels (d), thus playing a central role in the T1D pathogenesis. IL-6, in synergy with TGF $\beta$, is able to promote $\mathrm{T}_{\mathrm{H}} 17$ differentiation (e). Another $\mathrm{T}_{\mathrm{H}} 17$ differentiation pathway involves TGF $\beta$ and IL-23, whose levels are increased in obese subjects (f). Differentiated $\mathrm{T}_{\mathrm{H}} 17$ cells play a crucial role in both psoriasis and $\mathrm{T} 1 \mathrm{D}$, and increased levels of $\mathrm{T}_{\mathrm{H}} 17$ cells could exacerbate these diseases $(\mathbf{g})$. IL-18 levels are increased in psoriasis, T1D, and obesity (h). TNF is not represented in order to simplify the reading of the scheme.

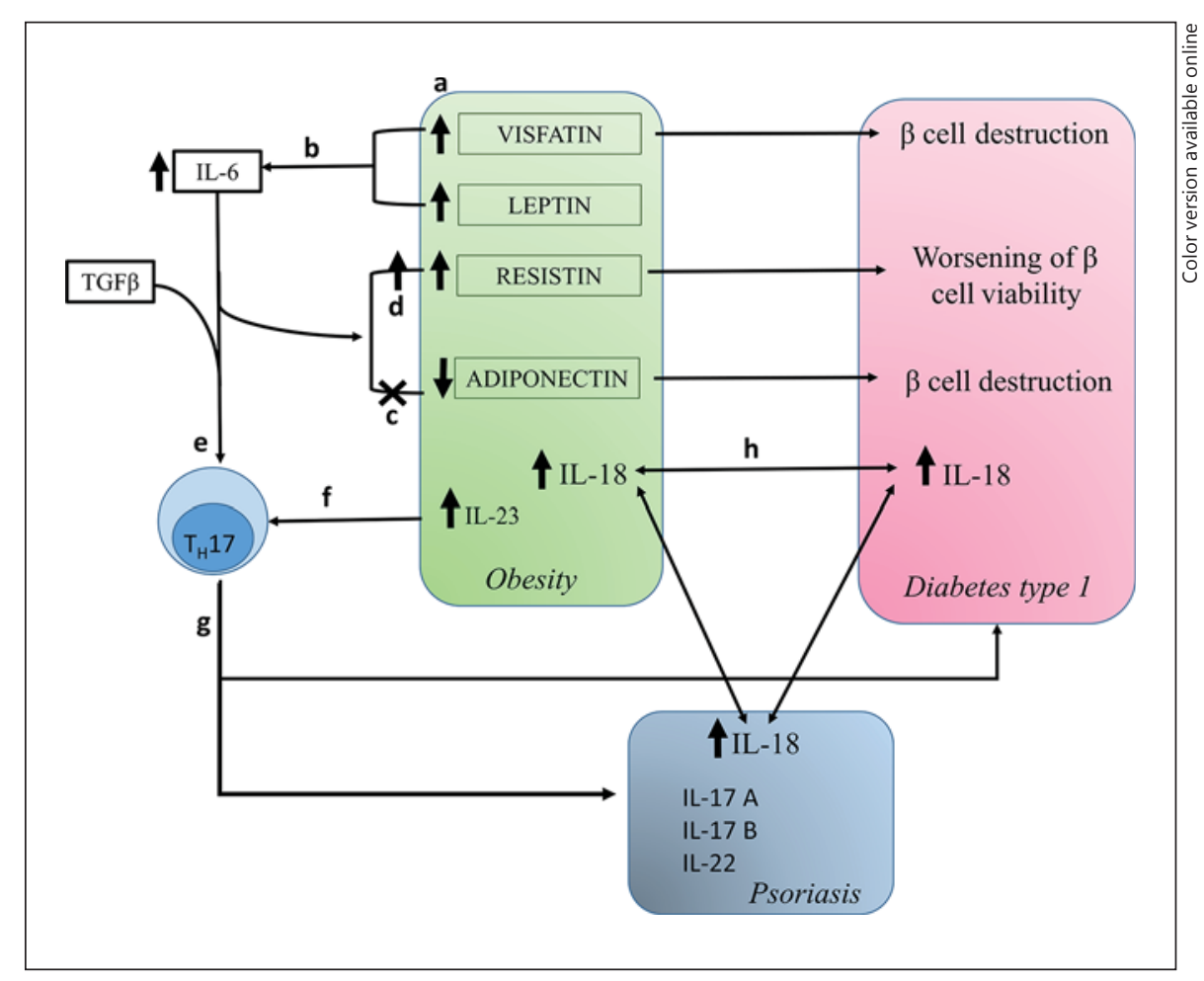

proteins, plays a central role in the TNF signaling pathway [100]. However, it is worthwhile to underline that the role of miR-21 and miR-146a in psoriasis, as in other autoimmune diseases, is unknown and remains to be investigated in detail.

\section{T1D and Psoriasis}

Psoriasis and diabetes are both associated with chronic inflammation due to TNF and other proinflammatory cytokines, such as IL-1 and IL-6 [101]. The beneficial effects that many drugs have on both psoriasis and T1D may underline the correlation between these diseases. First approved for the treatment of moderate-to-severe psoriasis, alefacept is a biological drug tested in the T1DAL (inducing remission in new-onset type 1 diabetes with alefacept) trial [102]. This study has shown that alefacept is able to target pathogenic effector T cells, preventing $\beta$ cell destruction in patients with new-onset T1D [103]. In particular, the fusion protein alefacept binds CD2 on T cells, thus inhibiting its interaction with CD58 on antigen-presenting cells, blocking ultimately the $\mathrm{T}_{\mathrm{H}} 1$ and $\mathrm{T}_{\mathrm{H}} 17$ polarization required for the onset and maintenance of these diseases [104]. Ustekinumab is a monoclonal antibody currently approved and validated in patients under psoriasis treatment. This antibody targets the shared p40 subunit of IL-12 and IL-23, thus inhibiting both IFN- $\gamma$ and IL-17 signaling pathways, respectively [105]. IL-12 differentiates naïve T cells into the $\mathrm{T}_{\mathrm{H}} 1$ phenotype, which is known to be involved in both psoriasis and T1D. Furthermore, IL-23-driven $\mathrm{T}_{\mathrm{H}} 17$ polarization plays a critical role in the onset of both diseases [106].

\section{Obesity and T1D}

Adipokines play a crucial role in the relationship between T1D and obesity, since their action involves metabolism, immunity, and obesity. Leptin and adiponectin regulate glucose metabolism through different mechanisms, including promotion of insulin secretion and glucose storage [107]. Recent studies have found high levels of adipokines in patients with T1D, suggesting a compensatory mechanism secondary to hyperglycemia, as well as the loss of endogenous insulin secretion in T1D patients [108]. Adiponectin has also been shown to protect $\beta$ cells from apoptosis and islet immunoreactivity [109], while resistin has been shown to decrease $\beta$ cell 
viability [110]. Resistin is also involved in insulin resistance and its levels have been found to be increased in T1D [111], suggesting that it may be involved in the pathogenesis of this disease. Indeed, leptin has proinflammatory effects and accelerates autoimmune destruction of $\beta$ cells in murine models [112]. Thanks to this knowledge on adipokines, it is clear that the prevention of obesity may have substantial benefits for preventing late complications of T1D.

\section{Obesity and Psoriasis}

Many studies have shown that patients with psoriasis are more frequently overweight or obese than the general population. There are strong pieces of evidence suggesting that obesity is an independent risk factor for psoriasis [113]. Furthermore, it has been indicated that obesity is more prevalent in patients with severe psoriasis than in patients with the mild form, reinforcing the link between body fat mass and psoriasis [3]. Extensive data, acquired on the proinflammatory role of adipocytes, show the pathogenic role of obesity in the incidence of psoriasis and in its severity. Adipokines and other mediators secreted by adipocytes may contribute to the inflammatory state in psoriasis [114]. Many studies have found that both leptin and resistin levels were higher in psoriatic patients than healthy controls, with a strong correlation to the severity of the disease $[115,116]$. Recent studies have started focusing on dermal adipose tissue, and preliminary data have shown that psoriasis might interact systemically with subcutaneous white adipose tissue or locally with dermal white adipose tissue [117]. Nevertheless, psoriasis and obesity may be not reciprocally or unidirectionally causal, and instead may derive from a shared pathophysiology [118].

\section{Conclusion}

In conclusion, as summarized in figure 1, literature data highlight the strong relationship between obesity, $\mathrm{T} 1 \mathrm{D}$, and psoriasis. In particular, the IL-23/IL-17 axis may be involved in the pathogenesis of these three diseases, highlighting the occurrence of a common causal link among these systemic inflammatory diseases. Furthermore, the IL-18 axis plays a central role in the link between these diseases, because it is involved in the regulation of energy homeostasis, its genes are associated with T1D susceptibility and its levels have been found higher in active and progressive psoriatic lesions. The combination of genetic, epigenetic, and environmental factors is highly suspected to promote this triple flip. There is strong evidence for the negative impact of obesity on several autoimmune diseases. The adipose tissue is an active endocrine organ that may play a central role in the onset as well as in the worsening of pathological conditions in obese subjects. Adipokines may contribute to the inflammatory state in psoriasis as well as their dysregulation may have an important effect on $\beta$ cell viability. Furthermore, miR-21 and miR-146a have been found to have an important role in these diseases. The discovery of stable, reproducible, and tissue-specific miRNAs in serum supports the potential role for use as novel biomarkers.

Many studies have focused on the treatment of autoimmune diseases with immune system-regulating drugs. In particular, new drugs targeting common inflammatory pathways could be helpful in the treatment of these diseases. Conditions such as obesity, psoriasis, and/or T1D can interfere in the efficacy of treatment and have shown to have a huge effect on public health. Mechanisms underlying the shared pathophysiological events need further studies in order to help clinicians in the management of these patients.

\section{References}

1 Ceribelli A, Generali E, Selmi C: Environment and autoimmunity: facts and gaps; in Esser C (ed): Environmental Influences on the Immune System. Berlin, Springer, 2016, pp 305-320.

2 van der Meer JW, Netea MG: A salty taste to autoimmunity. N Engl J Med 2013;368:25202521.

3 Procaccini C, Carbone F, Galgani M, La Rocca C, De Rosa V, Cassano S, Matarese G: Obesity and susceptibility to autoimmune diseases. Expert Rev Clin Immunol 2011;7:287-294.
4 Landsberg L, Aronne LJ, Beilin LJ, Burke V, Igel LI, Lloyd-Jones D, Sowers J: Obesity-related hypertension: pathogenesis, cardiovascular risk, and treatment - a position paper of The Obesity Society and The American Society of Hypertension. Obesity (Silver Spring) 2013;21:8-24.

5 Booth A, Magnuson A, Fouts J, Foster MT: Adipose tissue: an endocrine organ playing a role in metabolic regulation. Horm Mol Biol Clin Investig 2016;26:25-42.
6 Versini M, Jeandel PY, Rosenthal E, Shoenfeld Y: Obesity in autoimmune diseases: not a passive bystander. Autoimmun Rev 2014;13: 981-1000.

7 Naylor C, Petri WA Jr: Leptin regulation of immune responses. Trends Mol Med 2016;22: 88-98.

8 Park HK, Ahima RS: Physiology of leptin: energy homeostasis, neuroendocrine function and metabolism. Metabolism 2015;64:24-34. 
9 Brennan AM, Mantzoros CS: Drug insight: the role of leptin in human physiology and pathophysiology - emerging clinical applications. Nat Clin Pract Endocrinol Metab 2006; 2:318-327.

10 Alomar SY, Gentili A, Zaibi MS, Kępczyńska MA, Trayhurn P: IL-1 $\beta$ (interleukin-1 $\beta$ ) stimulates the production and release of multiple cytokines and chemokines by human preadipocytes. Arch Physiol Biochem 2016;18:1-18.

11 Stofkova A: Resistin and visfatin: regulators of insulin sensitivity, inflammation and immunity. Endocr Regul 2010;44:25-36.

12 Zeng H, Hongbo C: The interplay between regulatory $\mathrm{T}$ cells and metabolism in immune regulation. Oncoimmunology 2013;2:e26586.

13 Peng J, Tsang JY, Ho DH, Zhang R, Xiao H, Li D, Zhu J, Wang F, Bian Z, Lui VC, Xu A, Tam PK, Lamb JR, Xia H, Chen Y: Modulatory effects of adiponectin on the polarization of tumor-associated macrophages. Int J Cancer 2015; 137:848-858.

14 van Stijn CM, Kim J, Lusis AJ, Barish GD, Tangirala RK: Macrophage polarization phenotype regulates adiponectin receptor expression and adiponectin anti-inflammatory response. FASEB J 2015;29:636-649.

15 Li L, Wu LL: Adiponectin and interleukin-6 in inflammation-associated disease. Vitam Horm 2012;90:375-395.

16 Toussirot E, Gaugler B, Bouhaddi M, Nguyen NU, Saas P, Dumoulin G: Elevated adiponectin serum levels in women with systemic autoimmune diseases. Mediators Inflamm 2010; 2010:938408.

17 Ramos-Ramírez P, Malmhäll C, Johansson K, Lötvall J, Bossios A: Weight gain alters adiponectin receptor 1 expression on adipose tissue-resident Helios+ regulatory T cells. Scand J Immunol 2016;83:244-254.

18 Krysiak R, Handzlik-Orlik G, Okopien B: The role of adipokines in connective tissue diseases. Eur J Nutr 2012;51:513-528.

19 Stavropoulos-Kalinoglou A, Metsios GS, Koutedakis Y, Kitas GD: Obesity in rheumatoid arthritis. Rheumatology (Oxford) 2011; 50:450-462.

20 Cao H: Adipocytokines in obesity and metabolic disease. J Endocrinol 2014;220:47-59.

21 Gomez-Tourino I, Arif S, Eichmann M, Peakman M: T cells in type 1 diabetes: instructors, regulators and effectors: a comprehensive review. J Autoimmun 2016;66:7-16.

22 Atkinson MA, Bluestone JA, Eisenbarth GS, Hebrok M, Herold KC, Accili D, Pietropaolo M, Arvan PR, Von Herrath M, Markel DS, Rhodes CJ: How does type 1 diabetes develop? The notion of homicide or $\beta$-cell suicide revisited. Diabetes 2011;60:1370-1379.

23 Jaberi-Douraki M, Schnell S, Pietropaolo M, Khadra A: Unraveling the contribution of pancreatic $\beta$-cell suicide in autoimmune type 1 diabetes. J Theor Biol 2015;375:77-87.

24 Jain R, Tartar DM, Gregg RK, Divekar RD, Bell JJ, Lee HH, Yu P, Ellis JS, Hoeman CM, Franklin CL, Zaghouani H: Innocuous IFN $\gamma$ induced by adjuvant-free antigen restores normoglycemia in NOD mice through inhibition of IL-17 production. J Exp Med 2008;205: 207-218.

25 Emamaullee JA, Davis J, Merani S, Toso C, Elliott JF, Thiesen A, Shapiro AM: Inhibition of Th17 cells regulates autoimmune diabetes in NOD mice. Diabetes 2009;58:1302-1311.

26 Alnek K, Kisand K, Heilman K, Peet A, Varik K, Uibo R: Increased blood levels of growth factors, proinflammatory cytokines, and Th17 cytokines in patients with newly diagnosed type 1 Diabetes. PLoS One 2015;10: e0142976.

27 Bartlett HS, Million RP: Targeting the IL-17$\mathrm{T}_{\mathrm{H}} 17$ pathway. Nat Rev Drug Discov 2015;14: 11-12.

28 Wang C, Guan Y, Yang J: Cytokines in the progression of pancreatic $\beta$-cell dysfunction. Int J Endocrinol 2010;2010:515136.

29 Wilcox NS, Rui J, Hebrok M, Herold KC: Life and death of $\beta$ cells in type 1 diabetes: a comprehensive review. J Autoimmun 2016;71:5158.

30 Coates L, Savage L, Emery P: Pathogenesis of psoriasis and psoriatic arthritis; in Warren R, Menter A (eds): Handbook of Psoriasis and Psoriatic Arthritis. Basel, Springer, 2016, pp $7-16$

31 Ayala-Fontánez N, Soler DC, McCormick TS: Current knowledge on psoriasis and autoimmune diseases. Psoriasis Targets Therapy 2016;6:7-32.

32 Kirkham B: Innate and acquired cellular immune responses in psoriasis and psoriatic arthritis; in Adebajo A, Boehncke W-H, Gladman DD, Mease JP (eds): Psoriatic Arthritis and Psoriasis. Basel, Springer, 2016, pp 61-72.

33 Saxena A, Raychaudhuri SK, Raychaudhur SP: Cytokine pathways in psoriasis and psoriatic arthritis; in Adebajo A, Boehncke W-H, Gladman DD, Mease JP (eds): Psoriatic Arthritis and Psoriasis. Basel, Springer, 2016, pp 73-82.

34 Zhang L, Yang XQ, Cheng J, Hui RS, Gao TW: Th17 cells are accompanied by FoxP ${ }^{+}$Treg cell accumulation and correlated with psoriasis disease severity. Clin Immunol 2010;135: 108-117.

35 Bovenschen HJ, van de Kerkhof PC, van Erp PE, Woestenenk R, Joosten I, Koenen HJ: Foxp3+ regulatory $\mathrm{T}$ cells of psoriasis patients easily differentiate into IL-17A-producing cells and are found in lesional skin. J Invest Dermatol 2011;131:1853-1860.

36 Yang L, Li B, Dang E, Jin L, Fan X, Wang G: Impaired function of regulatory $\mathrm{T}$ cells in $\mathrm{pa}$ tients with psoriasis is mediated by phosphorylation of STAT3. J Dermatol Sci 2016;81: 85-92.

37 Lee JH, Cho DH, Park HJ: IL-18 and cutaneous inflammatory diseases. Int J Mol Sci 2015; 16:29357-29369.

38 Gisondi P, Tessari G, Conti A, Piaserico S, Schianchi S, Peserico A, Giannetti A, Girolomoni G: Prevalence of metabolic syndrome in patients with psoriasis: a hospital-based casecontrol study. Br J Dermatol 2007;157:68-73.
39 Coban M, Tasli L, Turgut S, Özkan S, Tunç Ata M, Akın F: Association of adipokines, insulin resistance, hypertension and dyslipidemia in patients with psoriasis vulgaris. Ann Dermatol 2016;28:74-79.

40 Polsky S, Ellis SL: Obesity, insulin resistance, and type 1 diabetes mellitus. Curr Opin Endocrinol Diabetes Obes 2015;22:277-282.

41 Langrish CL, Chen Y, Blumenschein WM, Mattson J, Basham B, Sedgwick JD, McClanahan T, Kastelein RA, Cua DJ: IL-23 drives a pathogenic $\mathrm{T}$ cell population that induces autoimmune inflammation. J Exp Med 2005; 201:233-240.

42 Morishima N, Mizoguchi I, Takeda K, Mizuguchi J, Yoshimoto T: TGF- $\beta$ is necessary for induction of IL-23R and Th17 differentiation by IL- 6 and IL-23. Biochem Biophys Res Commun 2009;386:105-110.

43 Sakaguchi S, Yamaguchi T, Nomura T, Ono M: Regulatory $\mathrm{T}$ cells and immune tolerance. Cell 2008;133:775-787.

44 Bettelli E, Carrier Y, Gao W, Korn T, Strom TB, Oukka M, Weiner HL, Kuchroo VK: Reciprocal developmental pathways for the generation of pathogenic effector TH17 and regulatory T cells. Nature 2006;441:235258.

45 Mangan PR, Harrington LE, O'Quinn DB, Helms WS, Bullard DC, Elson CO, Hatton RD, Wahl SM, Schoeb TR, Weaver CT: Transforming growth factor- $\beta$ induces development of the $\mathrm{T}(\mathrm{H}) 17$ lineage. Nature 2006;441: 231-234.

46 Yang XO, Panopoulos AD, Nurieva R, Chang SH, Wang D, Watowich SS, Dong C: STAT3 regulates cytokine-mediated generation of inflammatory helper T cells. J Biol Chem 2007; 282:9358-9363.

47 Kumar P, Subramaniyam G: Molecular underpinnings of Th17 immune-regulation and their implications in autoimmune diabetes. Cytokine 2015;71:366-376.

48 Lago F, Dieguez C, Gómez-Reino J, Gualillo $\mathrm{O}$ : The emerging role of adipokines as mediators of inflammation and immune responses. Cytokine Growth Factor Rev 2007;18:313325.

49 Sumarac-Dumanovic M, Stevanovic D, Ljubic A, Jorga J, Simic M, Stamenkovic-Pejkovic D, Starcevic V, Trajkovic V, Micic D: Increased activity of interleukin-23/interleukin-17 proinflammatory axis in obese women. Int J Obes (Lond) 2009;33:151-156.

50 Honkanen J, Nieminen JK, Gao R, Luopajarvi K, Salo HM, Ilonen J, Knip M, Otonkoski T, Vaarala O: IL-17 immunity in human type 1 diabetes. J Immunol 2010;185:1959-1967.

51 Bradshaw EM, Raddassi K, Elyaman W, Orban T, Gottlieb PA, Kent SC, Hafler DA: Monocytes from patients with type 1 diabetes spontaneously secrete proinflammatory cytokines inducing Th17 cells. J Immunol 2009; 183:4432-4439.

52 Wong FS, Wen L: Therapy: immunotherapy for T1DM - targeting innate immunity. Nat Rev Endocrinol 2013;9:384-385. 
53 Ferraro A, Socci C, Stabilini A, Valle A, Monti P, Piemonti L, Nano R, Olek S, Maffi P, Scavini $\mathrm{M}$, Secchi A, Staudacher C, Bonifacio E, Battaglia M: Expansion of Th17 cells and functional defects in T regulatory cells are key features of the pancreatic lymph nodes in patients with type 1 diabetes. Diabetes 2011;60: 2903-2913.

54 Annunziato F, Cosmi L, Santarlasci V, Maggi L, Liotta F, Mazzinghi B, Parente E, Filì L, Ferri S, Frosali F, Giudici F, Romagnani P, Parronchi $\mathrm{P}$, Tonelli F, Maggi E, Romagnani S: Phenotypic and functional features of human Th17 cells. J Exp Med 2007;204:1849-1861.

55 Reinert-Hartwall L, Honkanen J, Salo HM, Nieminen JK, Luopajärvi K, Härkönen T, Veijola R, Simell O, Ilonen J, Peet A, Tillmann V, Knip M, Vaarala O; DIABIMMUNE Study Group; DIABIMMUNE Study Group: Th1/ Th17plasticity is a marker of advanced $\beta$ cell autoimmunity and impaired glucose tolerance in humans. J Immunol 2015;194:68-75.

56 Walker LS, von Herrath M: CD4 T cell differentiation in type 1 diabetes. Clin Exp Immunol 2016;183:16-29.

57 Di Cesare A, Di Meglio P, Nestle FO: The IL23/Th17 axis in the immunopathogenesis of psoriasis. J Invest Dermatol 2009;129:13391350.

58 Nakajima K: Critical role of the interleukin23/T-helper 17 cell axis in the pathogenesis of psoriasis. J Dermatol 2012;39:219-224.

59 Lewis BJ, Rajpara S, Haggart AM, Wilson HM, Barker RN, Ormerod AD: Predominance of activated, clonally expanded $\mathrm{T}$ helper type 17 cells within the CD4+ T cell population in psoriatic lesions. Clin Exp Immunol 2013;173:38-46.

60 Bedoya SK, Lam B, Lau K, Larkin J 3rd: Th17 cells in immunity and autoimmunity. Clin Dev Immunol 2013;2013:986789.

61 Lindegaard B, Hansen AB, Pilegaard H, Keller P, Gerstoft J, Pedersen BK: Adipose tissue expression of IL-18 and HIV-associated lipodystrophy. AIDS 2004;18:1956-1958.

62 Skurk T, Kolb H, Müller-Scholze S, Röhrig K, Hauner H, Herder C: The proatherogenic cytokine interleukin-18 is secreted by human adipocytes. Eur J Endocrinol 2005; 152:863868.

63 Leick L, Lindegaard B, Stensvold D, Plomgaard P, Saltin B, Pilegaard H: Adipose tissue interleukin-18 mRNA and plasma interleukin-18: effect of obesity and exercise. Obesity (Silver Spring) 2007;15:356-363

64 Esposito K, Pontillo A, Ciotola M, Di Palo C, Grella E, Nicoletti G, Giugliano D: Weight loss reduces interleukin-18 levels in obese women. J Clin Endocrinol Metab 2002;87: 3864-3866.

65 Olusi SO, Al-Awadhi A, Abraham M: Relations of serum interleukin 18 levels to serum lipid and glucose concentrations in an apparently healthy adult population. Horm Res 2003;60:29-33

66 Fain JN: Release of interleukins and other inflammatory cytokines by human adipose tis- sue is enhanced in obesity and primarily due to the nonfat cells. Vitam Horm 2006;74:443477.

67 Barksby HE, Lea SR, Preshaw PM, Taylor JJ: The expanding family of interleukin-1 cytokines and their role in destructive inflammatory disorders. Clin Exp Immunol 2007;149: 217-225.

68 Sarvetnick N: IFN- $\gamma$, IGIF, and IDDM. J Clin Invest 1997;99:371-372.

69 Katakami N, Kaneto H, Matsuhisa M, Yoshiuchi K, Kato K, Yamamoto K, Umayahara Y, Kosugi K, Hori M, Yamasaki Y: Serum interleukin-18 levels are increased and closely associated with various soluble adhesion molecule levels in type 1 diabetic patients. Diabetes Care 2007;30:159-161.

70 Altinova AE, Yetkin I, Akbay E, Bukan N, Arslan M: Serum IL-18 levels in patients with type 1 diabetes: relations to metabolic control and microvascular complications. Cytokine 2008;42:217-221.

71 Frigerio S, Holländer GA, Zumsteg U: Functional IL-18 is produced by primary pancreatic mouse islets and NIT- $1 \beta$ cells and participates in the progression towards destructive insulitis. Horm Res 2002;57:94-104.

72 Aida K, Nishida Y, Tanaka S, Maruyama T, Shimada A, Awata T, Suzuki M, Shimura $\mathrm{H}$, Takizawa S, Ichijo M, Akiyama D, Furuya F, Kawaguchi A, Kaneshige M, Itakura J, Fujii H, Endo T, Kobayashi T: RIG-I- and MDA5-initiated innate immunity linked with adaptive immunity accelerates $\beta$-cell death in fulminant type 1 diabetes. Diabetes 2011;60:884-889.

73 Hanifi-Moghaddam P, Schloot NC, Kappler S, Seissler J, Kolb H: An association of autoantibody status and serum cytokine levels in type 1 diabetes. Diabetes 2003;52:1137-1142.

74 Naik SM, Cannon G, Burbach GJ, Singh SR, Swerlick RA, Wilcox JN, Ansel JC, Caughman S: Human keratinocytes constitutively express interleukin-18 and secrete biologically active interleukin-18 after treatment with pro-inflammatory mediators and dinitrochlorobenzene. J Invest Dermatol 1999;113: 766-772.

75 Johansen C, Moeller K, Kragballe K, Iversen $\mathrm{L}$ : The activity of caspase- 1 is increased in lesional psoriatic epidermis. J Invest Dermatol 2007; $127: 2857-2864$.

76 Companjen A, van der Wel L, van der Fits L, Laman J, Prens E: Elevated interleukin-18 protein expression in early active and progressive plaque-type psoriatic lesions. Eur Cytokine Netw 2004;15:210-216.

77 Gangemi S, Merendino RA, Guarneri F, Min ciullo PL, DiLorenzo G, Pacor M, Cannavò SP: Serum levels of interleukin-18 and sICAM- 1 in patients affected by psoriasis: preliminary considerations. J Eur Acad Dermatol Venereol 2003;17:42-46

78 Gutzmer R, Langer K, Mommert S, Wittmann M, Kapp A, Werfel T: Human dendritic cells express the IL-18R and are chemoattracted to IL-18. J Immunol 2003;171:63636371.
79 Perera RJ, Ray A: MicroRNAs in the search for understanding human diseases. BioDrugs 2007;21:97-104.

80 de Candia P, De Rosa V, Casiraghi M, Matarese G: Extracellular RNAs: secret arm of immune system regulation. J Biol Chem 2016; 291:7221-7228.

81 Sonkoly E, Wei T, Janson PC, Sääf A, Lundeberg L, Tengvall-Linder M, Norstedt G, Alenius $\mathrm{H}$, Homey B, Scheynius $\mathrm{A}$, Ståhle $\mathrm{M}, \mathrm{Pi}$ varcsi A: MicroRNAs: novel regulators involved in the pathogenesis of psoriasis? PLoS One 2007;2:e610.

82 Arner P, Kulyté A: MicroRNA regulatory networks in human adipose tissue and obesity. Nat Rev Endocrinol 2015;11:276-288.

83 Farh KK, Grimson A, Jan C, Lewis BP, Johnston WK, Lim LP, Burge CB, Bartel DP: The widespread impact of mammalian microRNAs on mRNA repression and evolution. Science 2005;310:1817-1821.

$84 \mathrm{Lu}$ LF, Boldin MP, Chaudhry A, Lin LL, Taganov KD, Hanada T, Yoshimura A, Baltimore D, Rudensky AY: Function of miR-146a in controlling $\mathrm{T}$ reg cell-mediated regulation of Th1 responses. Cell 2010;142:914-929.

85 Jeker LT, Bluestone JA: MicroRNA regulation of T-cell differentiation and function. Immunol Rev 2013;253:65-81.

86 de Santi C, Greene CM: The biology of microRNA; in Greene CM (ed): MicroRNAs and Other Non-Coding RNAs in Inflammation. Progress in Inflammation Research. Basel, Springer, 2015, pp 3-19.

87 Chartoumpekis DV, Zaravinos A, Ziros PG, Iskrenova RP, Psyrogiannis AI, Kyriazopoulou VE, Habeos IG: Differential expression of microRNAs in adipose tissue after long-term high-fat diet-induced obesity in mice. PLoS One 2012;7:e34872.

88 Huang ZH, Gu D, Mazzone T: Role of adipocyte-derived apoE in modulating adipocyte size, lipid metabolism, and gene expression in vivo. Am J Physiol Endocrinol Metab 2009; 296:E1110-E1119.

89 Price NL, Fernández-Hernando C: miRNA regulation of white and brown adipose tissue differentiation and function. Biochim Biophys Acta DOI: 10.1016/j.bbalip.2016.02.010.

90 Chen L, Dai YM, Ji CB, Yang L, Shi CM, Xu GF, Pang LX, Huang FY, Zhang CM, Guo XR: MiR-146b is a regulator of human visceral preadipocyte proliferation and differentiation and its expression is altered in human obesity. Mol Cell Endocrinol 2014;393:65-74.

91 Yang M, Ye L, Wang B, Gao J, Liu R, Hong J, Wang W, Gu W, Ning G: Decreased miR-146 expression in peripheral blood mononuclear cells is correlated with ongoing islet autoimmunity in type 1 diabetes patients. J Diabetes 2015;7:158-165.

92 Ruan Q, Wang T, Kameswaran V, Wei Q, Johnson DS, Matschinsky F, Shi W, Chen YH: The microRNA-21-PDCD4 axis prevents type 1 diabetes by blocking pancreatic $\beta$ cell death. Proc Natl Acad Sci USA 2011;108: 12030-12035. 
93 Zibert JR, Løvendorf MB, Litman T, Olsen J, Kaczkowski B, Skov L: MicroRNAs and potential target interactions in psoriasis. J Dermatol Sci 2010;58:177-185.

94 Meisgen F, Xu N, Wei T, Janson PC, Obad S, Broom O, Nagy N, Kauppinen S, Kemény L, Stanhle M, Pivarcsi A, Sonkoly E: MiR-21 is up-regulated in psoriasis and suppresses $\mathrm{T}$ cell apoptosis. Exp Dermatol 2012;21:312314.

95 Gu X, Nylander E, Coates PJ, Nylander K: Effect of narrow-band ultraviolet $\mathrm{B}$ phototherapy on $\mathrm{p} 63$ and microRNA (miR-21 and miR-125b) expression in psoriatic epidermis. Acta Derm Venereol 2011;91:392-397.

96 Murugaiyan G, da Cunha AP, Ajay AK, Joller N, Garo LP, Kumaradevan S, Yosef N, Vaidya VS, Weiner HL: MicroRNA-21 promotes Th17 differentiation and mediates experimental autoimmune encephalomyelitis. J Clin Invest 2015;125:1069-1080.

97 Guinea-Viniegra J, Jiménez M, Schonthaler HB, Navarro R, Delgado Y, Concha-Garzón MJ, Tschachler E, Obad S, Daudén E, Wagner EF: Targeting miR-21 to treat psoriasis. Sci Transl Med 2014;6:225re1.

98 Tang Y, Luo X, Cui H, Ni X, Yuan M, Guo Y, Huang X, Zhou H, de Vries N, Tak PP, Chen S, Shen N: MicroRNA-146A contributes to abnormal activation of the type I interferon pathway in human lupus by targeting the key signaling proteins. Arthritis Rheum 2009;60:1065-1075.

99 Taganov KD, Boldin MP, Chang KJ, Baltimore D: NFkB-dependent induction of microRNA miR-146, an inhibitor targeted to signaling proteins of innate immune responses. Proc Natl Acad Sci USA 2006;103: 12481-12486.

100 Pauley KM, Satoh M, Chan AL, Bubb MR, Reeves WH, Chan EK: Upregulated miR146a expression in peripheral blood mononuclear cells from rheumatoid arthritis patients. Arthritis Res Ther 2008;10:R101.
101 Pereira RR, Amladi ST, Varthakavi PK: A study of the prevalence of diabetes, insulin resistance, lipid abnormalities, and cardiovascular risk factors in patients with chronic plaque psoriasis. Indian J Dermatol 2011;56: 520-526.

102 Buzzetti R: Diabetes: Immunotherapy for T1DM - still not there yet. Nat Rev Endocrinol 2013;9:697-698.

103 Rigby MR, Harris KM, Pinckney A, DiMeglio LA, Rendell MS, Felner EI, Dostou JM, Gitelman SE, Griffin KJ, Tsalikian E, Gottlieb PA, Greenbaum CJ, Sherry NA, Moore WV, Monzavi R, Willi SM, Raskin P, KeyesElstein L, Long SA, Kanaparthi S, Lim N, Phippard D, Soppe CL, Fitzgibbon ML, McNamara J, Nepom GT, Ehlers MR: Alefacept provides sustained clinical and immunological effects in new-onset type 1 diabetes patients. J Clin Invest 2015;125:3285-3296.

104 Bluestone JA, Herold K, Eisenbarth G: Genetics, pathogenesis and clinical interventions in type 1 diabetes. Nature 2010;464: 1293-1300.

105 D'Amico F, Trovato C, Skarmoutsou E, Rossi GA, Granata M, Longo V, Gangemi P, Pettinato M, Mazzarino MC: Effects of adalimumab, etanercept and ustekinumab on the expression of psoriasin (S100A7) in psoriatic skin. J Dermatol Sci 2015;80:38-44.

106 Marwaha AK, Tan S, Dutz JP: Targeting the IL-17/IFN- $\gamma$ axis as a potential new clinical therapy for type 1 diabetes. Clin Immunol 2014;154:84-89.

107 Stofkova A: Leptin and adiponectin: from energy and metabolic dysbalance to inflammation and autoimmunity. Endocr Regul 2009;43:157-168.

108 Neumann T, Lodes S, Kästner B, Franke S, Kiehntopf M, Lehmann T, Müller UA, Wolf G, Sämann A: Osteocalcin, adipokines and their associations with glucose metabolism in type 1 diabetes. Bone 2016;82:50-55.

109 Imagawa A, Funahashi T, Nakamura T, Moriwaki M, Tanaka S, Nishizawa H, Sayama K, Uno S, Iwahashi H, Yamagata K, Miyagawa J, Matsuzawa Y: Elevated serum concentration of adipose-derived factor, adiponectin, in patients with type 1 diabetes. Diabetes Care 2002;25:1665-1666.
110 Pham MN, Kolb H, Mandrup-Poulsen T, Battelino T, Ludvigsson J, Pozzilli P, Roden M, Schloot NC; European C-Peptide Trial: Serum adipokines as biomarkers of $\beta$-cell function in patients with type 1 diabetes: positive association with leptin and resistin and negative association with adiponectin. Diabetes Metab Res Rev 2013;29:166-170.

111 Geyikli İ, Keskin M, Kör Y, Akan M: Increased resistin serum concentrations in patients with type 1 diabetes mellitus. J Clin Res Pediatr Endocrinol 2013;5:189-193.

112 Matarese G, Sanna V, Lechler RI, Sarvetnick N, Fontana S, Zappacosta S, La Cava A: Leptin accelerates autoimmune diabetes in female NOD mice. Diabetes 2002;51:13561361.

113 Setty AR, Curhan G, Choi HK: Obesity, waist circumference, weight change, and the risk of psoriasis in women: Nurses' Health Study II. Arch Intern Med 2007;167:16701675.

114 Takahashi H, Tsuji H, Honma M, IshidaYamamoto A, Iizuka H: Increased plasma resistin and decreased omentin levels in Japanese patients with psoriasis. Arch Dermatol Res 2013;305:113-116.

115 Zhu KJ, Zhang C, Li M, Zhu CY, Shi G, Fan YM: Leptin levels in patients with psoriasis: a meta-analysis. Clin Exp Dermatol 2013;38: 478-483.

116 Kawashima K, Torii K, Furuhashi T, Saito C, Nishio E, Nishida E, Shintani Y, Morita A Phototherapy reduces serum resistin levels in psoriasis patients. Photodermatol Photoimmunol Photomed 2011;27:152-155.

117 Kruglikov IL, Scherer PE, Wollina U: Are dermal adipocytes involved in psoriasis? Exp Dermatol DOI: 10.1111/exd.12996.

118 Sterry W, Strober BE, Menter A: Obesity in psoriasis: the metabolic, clinical and therapeutic implications. Report of an interdisciplinary conference and review. International Psoriasis Council. Br J Dermatol 2007;157: 649-655. 